\title{
Penanaman Nilai-Nilai Karakter Melalui Kegiatan Storytelling dengan Menggunakan Cerita Rakyat Sasak pada Anak Usia Dini
}

\author{
Sandy Ramdhani ${ }^{1 凶}$, Nur Adiyah Yuliastri ${ }^{2}$, Siti Diana Sari ${ }^{3}$, Siti Hasriah $^{4}$ \\ PG-PAUD FKIP Universitas Hamzanwadi ${ }^{1,2,3}$, TK Ummi Adniyah ${ }^{4}$
}

\begin{abstract}
This study aims to analyze the application of Sasak folklore based storytelling methods to be able to instill character values in kindergarten children in Ummi Adniyah NW Sekarteja Kindergarten. The research used is qualitative research. Type of approach from qualitative research used is descriptive approach. Data collection techniques are observation, interviews, and documentation. Data collection instruments used are the researchers themselves, Observation Sheets, and interviews. . Test the validity of trust data credibility test, Test Transferability, dependability and confirmability. The data analysis process was carried out using the Miles \& Huberman interactive analysis model: Data Collection, Data Display, Data Reduction, and Conclusion Drawing. The results of the study found that through storytelling activities using folklore is able to instill character values. Character values that emerge include the character of responsibility, independence, honesty, religion and cooperation. The characters that emerge are an accumulation that arises from the children's behavior after listening to the folklore that is used such as "lelampaq Lendong Kaoq" and "Tegodek-Godek and TetuntelTuntel".
\end{abstract}

Keywords: Character Values; Storytelling; Sasak Folklore; Kindergarten; Local Wisdom

\begin{abstract}
Abstrak
Penelitian ini bertujuan untuk menganalisis penerapan metode storytelling berbasis cerita rakyat sasak untuk menanamkan nilai-nilai karakter pada anak Taman Kanak-Kanak di TK Ummi Adniyah NW Sekarteja. Penelitian yang digunakan adalah penelitian kualitatif. Jenis Pendekatan yang digunakan adalah pendekatan deskriptif kualitatif. Teknik pengumpulan data adalah observasi, Wawancara, dan dokumentasi. Instumen pengumpulan data yang digunakan adalah peneliti, Lembar Observasi, dan wawancara. Uji keabsahan data dengan uji credibility, Uji Transferability, kebergantungan dependability dan kepastian confirmability. Proses analisis data dilakukan dengan menggunakan model analisis interaktif Miles \& Huberman yaitu Data Collection, Data Display, Data Reduction, dan Conclusion Drawing. Hasil dari penelitian didapatkan kegiatan storytelling dengan menggunakan cerita rakyat mampu untuk menanamkan nilai-nilai karakter. Nilai-nilai karakter yang muncul diantaranya adalah karakter tanggung jawab, mandiri, jujur, religious, dan kerjasama. Karakter yang muncul merupakan sebuah akumulasi yang muncul dari perilaku anak-anak setelah mendengarkan cerita rakyat yang digunakan seperti "lelampaq Lendong Kaoq" dan " Tegodek-godek dan Tetunteltuntel"
\end{abstract}

Kata Kunci : Nilai-Nilai Karakter;Cerita Rakyat Sasak; Taman Kanak-Kanak; Kearifan Lokal

@ Jurnal Obsesi Prodi PG-PAUD FIP UPTT 2019

$\triangle$ Corresponding author: Sandy Ramdhani

Address : Universitas Hamzanwadi

SSN 2356-1327 (Media Cetak)

Email : sandy160392@gmail.com

ISSN 2549-8959 (Media Online) 
154 | Penanaman Nilai-Nilai Karakter Melalui Kegiatan Storytelling

\section{PENDAHULUAN}

Pendidikan Anak Usia Dini merupakan suatu pendidikan yang mengembangkan berbagai aspek perkembangan anak mulai dari aspek perkembangan fisik-motorik, perkembangan kognitif, perkembangan bahasa, perkembangan nilai agama dan moral serta perkembangan seni (Kunci, 2017). (Lee, 2016) menjelaskan Semua aspek perkembangan merupakan capaian dan tujuan dari kegiatan pembelajaran di PAUD. Proses pembelajaran di di PAUD menekankan semua aspek perkembangan berhasil dalam perkembangan anak usia dini

Salah satu aspek perkembangan terpenting adalah nilai agama dan moral. (Fitroh et al., 2015) menyatakan Nilai agama dan moral tidak dapat dipisahkan dalam pembelajaran anak usia dini dikarenakan dalam UU no 137 tahun 2014 tentang standar Nasional Pendidikan Anak Usia Dini menjelaskan bahwa pendidikan karakter diterapkan dalam pembelajaran di PAUD. Penanaman nilai-nilai karakter sejak dini merupakan syarat wajib dalam pembelajaran di PAUD selain aspek perkembangan lainnya. (Thomas Lickona.2010) menjelaskan bahwa pendidikan karakter merupakan kebutuhan pokok dalam menciptakan manusia yang memiliki kepribadian dan perilaku yang baik.

(Wardani \& Widiyastuti, 2015) Proses penerapan pembelajaran pendidikan karakter di PAUD menjadi pusat dan tema utama dalam dunia pendidikan di Indonesia. Pemerintah Indonesia menekankan penanaman nilai-nilai karakter yang tidak hanya diterapkan di keluarga saja tetapi mulai diajarkan sejak awal dari taman kanak-kanak (kindergarten) hingga sekolah tinggi. Pendidikan karakter di sekolah semakin ditekankan sehingga dalam proses kegiatan pembelajaran selalu ada diselipkan tentang penanaman nilai karakter. (Rasyad, 2015) menjelaskan bahwa pengembangan nilai karakter merupakan aspek yang terkait dengan tingkat pengendalian diri yang dapat diberikan seorang individu dengan menampilkan perilaku internal atau eksternal yang dikontrol secara eksternal mengenai nilai-nilai universal di dalam masyarakat. Sehingga dalam prosesnya penanaman nilai-nilai karakter melalui proses pendidikan karakter di usia dini menjadi target dalam pembelajaran di AUD dan sangat mempengaruhi perkembangan anak.

Proses penerapan penanaman pendidikan karakter di PAUD masih terbatas tentang pengaplikasiannya dalam proses pembelajaran. (Choirun Nisak Aulina \& Aulina, 2013) Kebanyakan proses kegiatan pembelajaran di PAUD menekankan tentang aspek kognitif seperti kegiatan Calistung (Baca, Tulis, Hitung). Penekanan terhadap aspek kognitif di pembelajaran PAUD terutama di Taman Kanak-kanak menyebabkan aspek lainnya seperti aspek nilai agama dan moral, serta sosio-emosional tidak bisa berjalan dengan baik apalagi dalam penerapan pembelajaran ditekankan tentang pendidikan karakter dan proses pembelajarannya tidak berjalan dengan baik.

Penanaman nilai-nilai karakter menjadi sasaran penting di proses pembelajaran PAUD (Suyadi.2010). Anak sejak dini sudah diajarkan dan dilatih untuk menanamkan nilai-nilai karakter seperti tanggung jawab, jujur, mandiri dll. Penanaman nilai-nilai karakter dan moral sejak usia dini harus mengacu kepada aspek perkembangan anak. (Fitroh et al., 2015) Perkembangan anak usia dini terutama pada usia Taman kanak-kanak (TK) memiliki capaian-capaian 
perkembangan yang harus dicapai proses kegiatan pembelajarannya.

(Fitroh et al., 2015) menjelaskan Penanaman nilai-nilai karakter anak di usia Taman Kanak-Kanak membutuhkan metode pembelajaran yang bisa mengarahkan menuju pengajaran nilainilai karakter dan moral anak. Kebanyakan metode yang digunakan adalah metode kelompok dan klasikal dalam proses kegiatan pembelajarannya. Kegiatan pembelajaran yang baik dalam penerapan pembelajaran di Taman Kanak-Kanak adalah kegiatan pembelajaran yang merangsang rasa ingin tahu anak, motivasi anak, intelegensi anak, dan juga kesukaan anak. Salah satu kegiatan pembelajaran adalah dengan menggunakan metode Storytelling (Mendongeng) (Nur Azizah \& Ali, n.d. (2017).

Storytelling adalah penyampaian cerita kepada yang mendengarkan yang memiliki sifat menyenangkan, tidak menggurui dan dapat mengembangkan imajinasi (Alkaaf, 2017). cerita yang disajikan melalui storytelling akan mengisi memori anak dengan informasi dan nilainilai kehidupan. Banyak sekali cerita-cerita yang sangat bisa digunakan dalam kegiatan pembelajaran di TK (Moezzi, Janda, \& Rotmann, 2017). Cerita-cerita yang digunakan diantaranya adalah cerita dongeng, cerita rakyat, dan cerita pendek (cerpen).

Salah satu cerita yang digunakan dalam penerapan pembelajaran dengan menggunakan metode storytelling adalah cerita rakyat sasak. Cerita rakyat sasak diantaranya seperti "Cupak Gerantang, Lelampaq Lendong Kaoq, dan Rare Sigar. Ketiga cerita rakyat sasak ini merupakan cerita yang dapat digunakan dalam penerapan metode storytelling. Meskipun begitu cerita rakyat sasak lainnya dapat juga digunakan sebagai obyek kegiatan pembelajaran. Penanaman nilai-nilai karakter moral dengan metode storytelling menggunakan cerita rakyat suku sasak sebagai pengenalan nilai lokal kepada anak di Taman Kanak-Kanak Ummi Adniyah NW Sekarteja.

\section{METODOLOGI}

Penelitian yang digunakan adalah penelitian kualitatif. Jenis Pendekatan dari penelitian kualitatif yang digunakan adalah dengan pendekatan deskriptif. Sampel penelitian yang digunakan adalah di TK Ummi Adniyah NW Sekarteja dengan subjek anak kelompok A dan kelompok B. Teknik pengumpulan data adalah dengan menggunakan menggunakan observasi atau pengamatan, wawancara, dan Dokumentasi. Instumen pengumpulan data yang digunakan adalah human instrumen atau peneliti sendiri, pedoman wawancara dan juga lembar observasi. Uji keabsahan data untuk penelitian ini didasarkan dengan empat kriteria yaitu derajat kepercayaan (uji credibility), Keteralihan (Uji Transferability), kebergantungan (dependability) dan kepastian (confirmability). Proses analisis data dilakukan dengan menggunakan model analisis interaktif Miles \& Huberman (1994:12) yang diantaranya adalah : (1) Pengoleksian Data (Data Collection), (2) Display Data (Data Display), (3) Reduksi Data (Data Reduction), dan (4) Penggambaran hasil (Conclusion Drawing) (Miles \& Hubberman. 2001).

\section{HASIL DAN PEMBAHASAN}

\section{Hasil Penelitian}

TK Ummi Adniyah merupakan salah satu Taman Kanak-Kanak yang berada di dusun Pancor Sanggeng dengan jumlah siswa adalah 78 orang yang dibagi menjadi 1 kelas kelompok B dan 2 kelas kelompok A. kegiatan penanaman moral melalui 
kegiatan story telling dilakukan dengan menggunakan cerita rakyat sasak untuk menanamkan nilai-nilai karakter anak di TK Ummi Adniyah NW Sekarteja. Dari proses penerapan metode storytelling dalam menanamkan nilai karakter di TK Ummi Adniyah NW. proses kegiatan storytelling ini menggunakan cerita rakyat sasak yang mengajarkan dan menanamkan nilai karakter dan moral seperti tanggung jawab, religious, jujur, mandiri, dan lainnya.

Penanaman nilai karakter dan moral dilakukan dengan cara mengajarkan halhal baik dan buruk, proses kegiatan pembelajaran dalam menanamkan nilai karakter dan moral dengan cara mengajarkan sopan santun kepada anak dan melalui pemberian contoh-contoh sosok karakter tokoh yang diceritakan dalam kegiatan storytelling atau mendongeng tersebut misalkan saja dalam kisah "lelampak Lendong Kaoq" yang menjelaskan tokoh Sapi yang tidak puas terhadap apa yang didapatkannya, atau kisah "tegodek-Godek dan TetuntelTuntel” yang mengajarkan tentang keserakahan dan juga tidak ada rasa tanggung jawab memiliki serta egois. Dari kisah-kisah tersebut kemudian storytelling menjelaskan dampak yang didapatkan dari kegiatan bercerita. dengan mengdepankan , serta mengajarkan nilai-nilai karakter. Ketika cerita menjelaskan tentang sopan santun, sebaiknya mereka tak hanya memberikan sebatas narasi saja kepada anak, , tetapi juga contoh nyata. Kebiasaan mempunyai peranan penting dalam kehidupan manusia, karena ia menghemat banyak sekali kekuatan dan spontan agar kekuatan itu dapat dipergunakan untuk kegiatan-kegiatan di lapangan lain (Wardani \& Widiyastuti, 2015) Penanaman nilai Karakter dan Moral moral pada anak diperkenalkan melalui contohcontoh nyata dan ada yang ditiru. (Junaidi,
2017), menjelaskan penanaman nilai karakter dan moral moral pada anak usia dini diperkenalkan melalui proses pembiasaan pada tatanan kehidupan. Pernyataan tersebut cukup jelas bahwa sejak kecil anak harus dibiasakan berperilaku baik, sopan santun dan diperkenalkan nilai nilai kebaikan.

Hasil penelitian di TK Ummi Adniyah NW Sekarteja didapatkan adalah (a) Bentuk kegiatan strategi penanaman dan pengembangan nilai-nilai karakter didapatkan kegiatan yang dilakukan oleh guru sebagai storytelling . (b) Bentuk Kegiatan penanaman dan Pengembangan Nilai nilai Agama karakter melalui kegiatan terintegrasi.. (c) proses kegiatan storytelling dengan mengedepankan nilainilai karakter melalui cerita rakyat membuat siswa antusias dalam melaksanakan proses kegiatan bercerita tersebut. Proses kegiatan storytelling tersebut membuat anak-anak menjadi lebih bersemangat dalam proses pembelajarannya. (d) nilai-nilai karakter yang terlihat setelah pelaksanaan kegiatan storytelling tersebut adalah karakter tanggung jawab, jujur, religious, kerjasama, dan karakter mandiri. Semua nilai karakter tersebut terintegrasi dalam proses kegiatan pembelajaran setelah proses storytelling yang dilaksanakan.

\section{Pembahasan}

Indonesia sebagai negara yang menjunjung tinggi karakter, tentu memiliki dasar-dasar dalam merumuskan nilai karakter. Kemendiknas (2010:9-10) merumuskan nilai karakter sebagai berikut: 1)Religius, 2) jujur, 3) toleransi, 4) disiplin, 5) kerja keras, 6) kreatif, 7) mandiri, 8) demokratis, 9) rasa ingin tahu, 10) semangat kebangsaan, 11) cinta tanah air, 12) menghargai prestasi, 13) bersahabat atau komunikatif, 14) cinta damai, 15) gemar membaca, 16) peduli 
lingkungan, 17) peduli sosial, dan 18) tanggung jawab

Dongeng sendiri merupakan sebuah cerita yang tidak benar-benar terjadi atau sebuah cerita khayalan, dan Penanaman karaktek adalah pemberian suatu pendidikan yang membentuk akhlak atau budi pekerti yang membedakan seseorang dengan yang lain Hasil dari penelitian yang didapat adalah dongeng sebagai media dalam penanaman karakter sangatlah efektif untuk diterapkan kepada anak usia dini dan perlunya pembiasaan serta contoh yang baik untuk menumbuhkan karakter dari anak.

Kegiatan storytelling penekanannya adalah kinerja, elisitasi, dan konstruksi cerita atau narasi daripada menempatkan cerita sebagai objek. (Alkaaf, 2017) Storytelling adalah menggunakan cerita sebagai alat komunikasi dalam bernbagi pengetahuan. Dengan bercerita atau menyampaikan narasi menjadikan sebagai alat penghibur, dan memperkuat kemungkinan pengetahuan.

Story telling memberikan pengalaman bagi anak dalam proses pembelajarannya. kegiatan storytelling mendukung pemahaman anak dan sangat penting dalam perkembangan bahasa anak. Selain itu juga dengan kegiatan story telling membantu siswa memahami berbagai perbedaan multikultural dan pembelajaran kelompok. menjelaskan ada empat aspek yang mendasari cerita pada anak diantaranya adalah (1) mengingat informasi penting lebih banyak dan lebih luas ketika guru berbicara tentang cerita yang sudah dibaca; (2) ambil peran yang mereka ketahui ketika menceritakan kisah; (3) tempatkan kegiatan bercerita dengan urutan yang benar; (4) gunkan bahawa bercerita ketika menceritakan kembali sebuah cerita.
Nur Azizah \& Ali, (2017) metode Storytelling dilakukan dengan enam cara yaitu : (1) membaca langsung dari buku cerita; (2) menggunakan ilustrasi dari buku; (3) Mendongeng; (4) Menggunakan papan flanel;(5) menggunakan boneka; dan (6) memainkan jari-jari tangan. Cakra (2012) menjelaskan bahwa kriteria memilih cerita atau dongeng terdiri atas : (1) mengandung unsur-unsur alami pendidikan dan agama; (2) mengandung nasehat dan contoh suri tauladan dan akhlak yang mulia; (3) cerita tidak merusak kepribadian anak ; (4) berikan suasana yang menarik ketika menyampaikan dongeng (gembira, sedih atau marah dan sebagainya)

Dalam kegiatan storytelling dibagi atas dongeng, cerita, fiksi, dll. Cerita rakyat merupakan adalah cerita pada masa lampau yang melekat di lingkungan masyarakat . (Fitroh et al., 2015) menjelaskan cerita rakyat merupakan sarana pembelajaran budaya aik yang baik bagi anak karena mengangdung ciri khas, dan kultur budaya yang beraneka ragam dan mencakup kekayaan budaya dan sejarah yang dimiliki masing-masing daerah di indonesia. Cerita rakyat mampu mengembangkan potensi kognnitif, afektif, dan psikomotor anak. menjelaskan bahwa dalam cerita rakyat mengandung pesan moral yang ingin disampaikan tidak saja terdapat dalam karakter tokoh, tetapi juga alur yang berisi gagasan tertentu yang berkaitan dengan kehidupan manusia.

Pelaksanaan pembelajaran menggunakan kegiatan storytelling dapat meningkatkan kemampuan belajar anak dan memberikan efek positif tidak hanya perubahan nilai karakter saja, akan tetapi memotivasi anak dalam berprilaku dan melakukan aktifitas kegiatan pembelajaran (Liu \& Wang, 2010). (Varun, 2014) anak bermain secara terpadu dan menyeluruh sehingga mempengaruhi perkembangan 
usia muda anak. Masa anak-anak merupakan masa untuk mengeksplorasi, mengembangkan dan bermain. Wardani\&Widiastuti (2015) kegiatan storytelling berdampak pada Penerapan pembelajaran di TK dengan menggunakan pengenalan kearifan lokal dan potensi budaya daerah melalui cerita rakyat dapat memberikan sebuah hasil untuk perubahan perilaku anak dan pengenalan tentang keunggulan serta daerahnya itu sendiri.

Pembentukan karakter anak mulai sejak dini merupakan sebuah hal yang terpenting didalam proses kegiatan pembelajaran. Penanaman nilai karakter dengan mengedepankan nilai kearifan lokal mampu untuk membentuk nilai karakter anak. Hasil penelitian tentang kearifan lokal Wayang kancil yang dilakukan oleh (Wardani \& Widiyastuti, 2015) menjelaskan bahwa nilai kearifan lokal yang dikemas melalui Wayang kancil mampu untuk membuat beberapa nilai karakter untuk anak. Nilai-nilai karakter diantaranya adalah kemandirian dalam menyampaikan gagasan, kemampuan untuk bekerja sama dalam kelompok, disiplin (dalam waktu), kejujuran (melakukan tugas seseorang), demokratis (kemampuan untuk menerima ide orang lain atau kelompok lain), tanggung jawab dalam melakukan tugas dan menyelesaikan tugas atau tidak menghadapi hambatan. (Lisenbee \& Ford, 2018) pembelajaran di PAUD dengan menggunakan kegiatan storytelling digunakan untuk mengakomodasi pendidikan karakter dalam proses pembelajaran. perkembangan yang dibutuhkan untuk tetap untuk mengaplikasikan pembelajaran dan mengimprovisasi pendidikan carakter anak yang dipengaruhi oleh komitmen dan dukungan pihak sekolah, kesesuaian fasilitas, dan suasana yang ada di sekolah harus kondusif. Kearifan lokal merupakan aspek yang mendukung dalam pelaksanaan pembelajaran di TK karena menggunakan pengukuran seperti pemilihan tema yang digunakan sesuai daerah dan dihubungkan dengan tema lainnya, pemilihan tema dan sub tema untuk menidentifikasi dan mengenalkan anak dalam belajar dan struktur terpenting adalah indicator, kegiatan pembelajaran, sumber, pengetahuan untuk menstimulasi perkembangan anak (Nurmalina, 2016)

(Rukiyati \& Purwastuti, 2016) dalam pembelajaran di sekolah proses kegiatan pembelajaran tidak hanya mentransfer ilu pengetahuan saja, akan tetapi melalui kearifan lokal mampu untuk memberikan pembelajaran yang baik dan juga menghasilkan tentang nilai-nilai karakter yang didapatkan dengan menggunakan kearifan lokal nantinya karakter-karakter tersebut diantaranya adalah disiplin, tanggung jawab, kepedulian, religiusitas, semangat kebangsaan, mencintai tanah air, minat baca, berkorban, kreativitas, kejujuran, kemandirian dan kerja keras. (Lee, 2016) penanaman nilai karakter dengan musik sambil bermain sangat efektif dalam impelementasi pembelajaran di prasekolah, dikarenakan penanaman memberikan aksi tentang system sekolah,tergabung dalam kelompok bermain, pusat kegiatan rekreasi dan kegiatan tambahan sekolah. Hasilnya adalah bahwa nilai karakter tanggung jawab, jujur, hormat mampu untuk terbentuk. Nilai karakter tanggung jawab haruslah dilakukan dengan berbagai cara salah satunya adalah dengan menggunakan langkah tradisional (Penderi\&Rekalidou.2016). perkembangan tanggungjawab akan mempengaruhi perilaku anak. Aktivitas dengan penerapan musik dan instrument musik tradisional mempengaruhi perkembangan dari karakter anak tidak hanya tanggung jawab saja, tetapi jujur juga sangat terpengaruh 
oleh aspek-aspek tradisional (Angela Lee .2014)

Penanaman nilai karakter dengan menggunakan nilai-nilai kearifan lokal yang tercermin dari sebuah kebudayaan daerah. Permainan tradisional merupakan bagian dari kearifan lokal dan juga kebudayaan suatu daerah yang harus dilestarikan. Dahlia\&Soemarno (2015) menjelaskan bahwa kearifan lokal yang tercermin dari keunggulan suatu daerah yang tidak terkikis meski dipengaruhi oleh perkembangan teknologi dan budaya barat yang masuk kedalam kehidupan suatu masyarakat yang bisa mempengaruhi perubahan perilaku yang ada dilingkungan masyarakat tersebut. Ini juga termasuk ke dalam proses pembelajaran terutama pembelajaran pada anak usia dini. Penerapan proses pembelajaran dengan mengedepankan keunggulan daerah sejak dini menjadikan keberhasilan dalam penerapan proses pembelajaran tersebut (Wardani \& Widiyastuti, 2015),(Alkaaf, 2017).

(Pendidikan et al., 2018) Penerapan nilai-nilai kearifan lokal yang dikemas dalam permainan tradisional mampu untuk membentuk karakter anak. Pengemasan kearifan lokal melalui kegiatan storytelling tentu saja mampu untuk mengembangkan kemampuan tingkat pencapaian anak dapat membentuk karakter anak yang sudah tertuang dalam tujuan pendidikan bangsa Indonesia. Pembelajaran cerita rakyat sebagai penerapan kearifan lokal di PAUD dikarenakan bahwa dengan menceritakan keunggulan daerah maka mampu merangsang dan meningkatkan tingkat perkembangan anak (Nur Azizah \& Ali, n.d.) Pelaksanaan kegiatan storytelling tersebut merupakan alat untuk menanamnkan nilai kearifan local yang tertuang dalam cerita rakyat mampu mengembangkan tingkat kemampuan anak dan juga penanaman karakter.
Penanaman nilai karakter dengan kegiatan storytelling berbasis kearifan lokal dengan menggunakan cerita rakyatmerupakan sebuah dasar dalam penanaman nilai karakter di PAUD. Nilainilai yang ada dalam sebuah cerita Karakter jujur dan tanggung jawab masuk kedalam nilai agama dan moral dalam STTPA yang sudah diatur dalam Kemendikbud no 146 tahun 2014 tentang proses kegiatan pembelajaran anak usia dini. Dasar dari penerapan yang diatur dalam undang-undang tersebut menjadi acuan dalam penerapan proses pembelajaran di PAUD dan ketercapaian target yang diinginkan dalam pembelajaran di PAUD tentunya.

\section{SIMPULAN}

Kegiatan tanam moral melalui kegiatan story telling dilakukan menggunakan cerita rakyat Sasak untuk menanamkan nilai-nilai karakter anak-anak di TK Ummi Adniyah NW Sekarteja. Dari proses menerapkan metode mendongeng dalam menanamkan nilai-nilai karakter di TK Ummi Adniyah NW Sekarteja Bercerita memberikan pengalaman untuk anak-anak dalam proses pembelajaran. Kegiatan mendongeng mendukung pemahaman anak-anak dan sangat penting dalam perkembangan bahasa anak-anak.

\section{UCAPAN TERIMA KASIH}

Terima Kasih kepada Universitas Hamzanwadi, TK Ummi Adniyah NW Sekarteja, Tim Peneliti yang telah memberikan kelancaran dan kemudahan sejak proses penyusunan tulisan atau laporan sehingga memperoleh hasil riset yang bias digunakan sebagai kajian dalam proses Pendidikan pada Anak Usia Dini 
$160 \mid$ Penanaman Nilai-Nilai Karakter Melalui Kegiatan Storytelling

\section{DAFTAR PUSTAKA}

Alkaaf, F. (2017). Perspectives of learners and teachers on implementing the storytelling strategy as a way to develop story writing skills among middle school students. Cogent Education, 4(1), 1-23. https://doi.org/10.1080/2331186X.20 17.1348315

Choirun Nisak Aulina, \& Aulina, C. N. (2013). Penanaman Disiplin Pada Anak Usia Dini. Pedagogia, 2(1), 36-49.

https://doi.org/10.21070/pedagogia.v $2 \mathrm{i} 1.45$

Fitroh, S. F., Dwi, E., Sari, N., Studi, P., Guru, P., Anak, P., ... Madura, U. T. (2015). Dongeng Sebagai Media Penanaman Karakter Pada Anak Usia Dini. PG-PAUD Trunojoyo, 2.

Junaidi, F. (2017). the Value of Character Education in Andai-Andai Folklore and Its Use As Learning Material for, III(9), 501-509.

Kunci, K. (2017). Jurnal obsesi. FaktorFaktor Yang Berhubungan Dengan Perkembangan Bahasa Balita Di UPTD Kesehatan Baserah, 1(2), 148-155.

Lee, A. (2016). Implementing character education program through music and integrated activities in early childhood settings in Taiwan. International Journal of Music Education, 34(3), 340-351. https://doi.org/10.1177/02557614145 63195

Lisenbee, P. S., \& Ford, C. M. (2018). Engaging Students in Traditional and Digital Storytelling to Make Connections Between Pedagogy and Children's Experiences. Early Childhood Education Journal, 46(1), 129-139.

https://doi.org/10.1007/s10643-0170846-X

Liu, M. C., \& Wang, J. Y. (2010). Investigating knowledge integration in web-based thematic learning using concept mapping assessment. Educational Technology and Society, 13(2), 25-39.
Moezzi, M., Janda, K. B., \& Rotmann, S. (2017). Using stories, narratives, and storytelling in energy and climate change research. Energy Research and Social Science, 31(August), 110 .

https://doi.org/10.1016/j.erss.2017.06 .034

Nur Azizah, A., \& Ali, M. (n.d.). Penanaman Nilai Moral Melalui Metode Bercerita Pada Anak Usia 5 - 6 Tahun Di Tk Khodijah, 1-16.

Nurmalina. (2016). Jurnal paud tambusai. Jurnal Obsesi, 2, 73-78.

Pendidikan, J., Pendidikan, G., Usia, A., Volume, D., Tahun, N., Metode, P., ... Tahun, N. (2018). KARAKTER ANAK KELOMPOK B TK GUGUS MELATI KECAMATAN MARGA e-Journal Pendidikan Anak Usia Dini Universitas Pendidikan Ganesha, $6(1)$.

Rasyad, A. (2015). Developing a Parenting Training Model of Character Education for Young Learners from Poor Families by Using Transformative Learning Approach. International Education Studies, $8(8), \quad 50-56$. https://doi.org/10.5539/ies.v8n8p50

Rukiyati, \& Purwastuti, L. A. (2016). Model pendidikan karakter berbasis kearifan lokal pada Sekolah Dasar di Bantul Yogyakarta. Jurrnal Pendidikan Karakter, VI(1), 130142.

Varun, A. (2014). Thematic Approach for effective communication in ECCE, 3(3), 49-51.

Wardani, N. E., \& Widiyastuti, E. (2015). Integrated Thematic Learning Model Based on Wayang Kancil Which can be Used to Teach Character Education Values to Pupils of Elementary Schools in Surakarta, Indonesia. Asian Journal of Management Sciences \& Education, 4(April), 36-42. 